\title{
STUDI PERTUMBUHAN OKULASI BIBIT LAI (Durio kutejensis HASSK. BECC) VARIETAS MAHAKAM
}

\author{
(Growth Of Bud Grafting Seedling Of Lai (Durio Kutejensis Hassk. Becc) Var. Mahakam)
}

Candra Catur Nugroho, Sundari, dan Ahmad Hoiri Asabah

Program Studi Agroteknologi, Fakultas Pertanian Universitas Kutai Kartanegara

Jl. Gunung Kombeng No. 27 Tenggarong

Koresponden email: candracatur@unikarta.ac.id

Article Submitted : 28-05-2019

Article Accepted : 09-06-2019

\begin{abstract}
The aims of this experiment was to determine the effect of the application of Agrib Compost liquid organic fertilizer to the growth of bud grafting seedling of Lai (Durio kutejensis HASSK. BECC) var. Mahakam. The experiment used a Randominzed Block Design (RCBD) with Agrib Compost liquid organic fertilizer treatment (P) 8 level and 3 tests made up of $\mathrm{p}_{0}=$ without treatment (control), $\mathrm{p}_{1}=\left(2 \mathrm{ml} \mathrm{L}^{-1}\right.$ water $), \mathrm{p}_{2}=\left(4 \mathrm{ml} \mathrm{L}^{-1}\right.$ water $), \mathrm{p}_{3}=\left(6 \mathrm{ml} \mathrm{L}^{-1}\right.$ water $), \mathrm{p}_{4}=\left(8 \mathrm{ml} \mathrm{L}^{-}\right.$ ${ }^{1}$ water $), \mathrm{p}_{5}=\left(10 \mathrm{ml} \mathrm{L}^{-1}\right.$ water $), \mathrm{p}_{6}=\left(12 \mathrm{ml} \mathrm{L}^{-1}\right.$ water $), \mathrm{p}_{7}=\left(14 \mathrm{ml} \mathrm{L}^{-1}\right.$ water $)$. The result of the experiment indicated that the treatment of Agrib Compost liquid organic fertilizer, it had a very significant effect to the age of broken buds but had no significant effect to the length of bud parameters, the number of leaves and the diameter of the stem. The treatment of Agrib Compost liquid organic fertilizer $14 \mathrm{ml} \mathrm{L}^{-1}$ water, providing better growth in age parameters of broken buds, bud length, and the number of leaves.
\end{abstract}

Keywords: Lai, Bud Grafting Seedling, Agrib Compost Liquid Organic Fertilizer

\section{PENDAHULUAN}

Lai merupakan salah satu kerabat durian yang cukup prospektif untuk dikembangkan sebagai komoditas unggul di Indonesia. Durian lokal seperti lai dapat menjadi raja di negeri sendiri apabila buah lokal ini memiliki mutu yang baik. Mutu yang baik harus diimbangi dengan budidaya yang benar dan tepat, untuk menunjang pertumbuhan tanaman lai yang berkualitas dan dapat bersaing di pasar buah.

Prospek komoditas lai sangat baik mengingat permintaannya terus meningkat baik penikmat domestik maupun mancanegara. Berdasarkan hasil wawancara dengan pedagang buah lai di Desa Batuah Kecamatan Loa Janan pada bulan Agustus 2018, harga jual lai berkisar antara Rp.25.000
- Rp.50.000,-/ buah. Kandungan nutrisi lai terdiri dari gula $17 \%$ brix, kandungan protein $6,70 \%$, kandungan lemak 2,14\%, kandungan air 57,96\%, kandungan karbohidrat 19,05\%, kandungan serat kasar 2,28\% (Rizal dkk, 2015).

Pada tahun 2017 komoditas lai hanya ada di beberapa kecamatan saja, seperti Muara Jawa, Loa Janan, Loa Kulu, Sebulu, Tenggarong Seberang, Muara Badak, dan Muara Kaman. Hasil rekapitulasi setiap kecamatan di Kabupaten Kutai Kartanegara, dengan produksi dan produktifitasnya mencapai 20.340 pohon, dengan hasil produksi 2,5 ton dan produktivitas $12,29 \mathrm{~kg}$ per pohon (Dinas Pertanian Tanaman Pangan dan Hortikultura Kabupaten Kutai Kartanegara, 2018). 
Tanaman lai di setiap daerah di Kutai Kartanegara sangatlah kurang, hanya ada dijumpai di beberapa daerah saja. Hal ini disebabkan oleh umur berbuah yang terlalu lama, sehingga orang enggan menanamnya. Hal ini merupakan faktor penyebab terjadinya pengikisan plasma nutfah, sehingga keberadaan dan kelestarian tanaman durian lokal ini menjadi terancam. Kenyataan ini tentu memerlukan perhatian dari semua pihak dalam rangka pelestarian plasma nutfah khususnya lai, yang spesifik di Kalimantan. Dengan menanam komoditas tersebut pada kebun koleksi dan mempelajari teknik perbanyakan secara vegetatif (okulasi) untuk mempercepat umur berbuah (Santoso dan Priono, 2015).

Keahlian untuk melakukan perbanyakan secara vegetatif sangat diperlukan untuk meningkatkan hasil produksi lai. Salah satu keahlian yang diperlukan tersebut adalah teknik okulasi. Keunggulan okulasi yaitu mempercepat umur berbuah dan dapat melakukan perbanyakan dengan menetukan varietas unggul yang kita inginkan. Namun teknik dalam perbanyakan ini masih banyak yang belum mengetahuinya dan masih belum mahir dalam melakukan perbanyakannya.

Selain teknik perbanyakan tanaman yang menjadi kendala dalam memperbaiki sistem budidaya, ada juga aspek penunjang lainnya, yaitu pemberian nutrisi pada tanaman khususnya lai. Pemanfaatan pupuk organik menjadi pertimbangan penting di kalangan pembudidaya durian lokal ini. Pupuk organik ada 2 bentuk yaitu padat dan cair. Pupuk organik cair merupakan pupuk yang cepat mengalami penguraian dalam fermentasinya, dibandingkan pupuk padat. Pupuk organik cair lebih cepat diserap oleh tanaman bersamaan dengan penyerapan molekul air di dalam tanah dalam bentuk ion (melalui akar). Pemberian pupuk organik cair dapat langsung diaplikasikan ke media tanam ataupun disemprotkan langsung ke bagian organ tanaman seperti daun (Lisdiyanti, 2011).

Pupuk organik cair agrib kompos memilki beberapa keunggulan dibandingkan dengan pupuk orgaik cair lainya, seperti pemanfaatan urin ternak dan bahan organik lainnya yang ramah lingkungan. Selain itu, pupuk organik cair ini memiliki peranan mikroorganisme dan zat perangsang tumbuh, yang dapat menunjang kestabilan tanaman. (Priono, 2018).

Tujuan dari penelitian ini adalah untuk mengetahui pengaruh POC agrib kompos terhadap pertumbuhan okulasi bibit lai (Durio kutejensis HASKK BECC) varietas Mahakam.

\section{METODE PENELITIAN}

\section{Waktu dan Tempat}

Penelitian ini dilaksanakan pada bulan September sampai dengan November 2018, sejak persiapan tempat sampai pengambilan data terakhir. Tempat penelitian di Desa Batuah, Kecamatan Loa Janan, Kabupaten Kutai Kartanegara.

\section{Bahan dan Alat}

Bahan-bahan yang digunakan adalah entres lai varietas Mahakam, bibit lai (batang bawah), dan POC Agrib Kompos. Alat yang digunakan berupa pisau okulasi, gunting, handsprayer, kaliper, alat tulis, spidol permanen, penggaris, papan nama, dan kamera.

\section{Rancangan Penelitian}

Penelitian ini menggunakan Rancangan Acak Kelompok (RAK), dengan perlakuan pupuk organik cair agrib kompos (p) terdiri atas 8 taraf dan diulang sebanyak 3 kali. Taraf perlakuan yaitu $\mathrm{p}_{0}=$ tanpa perlakuan (kontrol), $\mathrm{p}_{1}=2 \mathrm{ml} \mathrm{L}^{-1}$ air, $\mathrm{p}_{2}=4 \mathrm{ml} \mathrm{L}^{-1}$ air, $\mathrm{p}_{3}=6 \mathrm{ml} \mathrm{L}^{-}$ ${ }^{1}$ air, $\mathrm{p}_{4}=8 \mathrm{ml} \mathrm{L}^{-1}$ air, $\mathrm{p}_{5}=10 \mathrm{ml} \mathrm{L}^{-1}$ air, $\mathrm{p}_{6}=$ $12 \mathrm{ml} \mathrm{L}^{-1}$ air, $\mathrm{p}_{7}=14 \mathrm{ml} \mathrm{L}^{-1}$ air.

\section{Pelaksanaan Penelitian}

\section{Persiapan tempat}

Tempat yang digunakan dibersihkan dari rerumputan, tunggul, sampah plastik dan sebagainya samapi benar-benar terlihat bersih. Tanah yang berguludan diratakan menggunakan cangkul sampai rata, sehingga polybag dapat disusun dengan baik dan rapi. 
2. Persiapan batang bawah dan mata tempel (entres)

Batang bawah diseleksi sesuai syarat batang bawah yakni terhindar dari serangan hama dan penyakit, tidak kerdil/bengkok, batang dan daun tidak kering, mudah dikupas dengan kuku (batang), dan minimal berumur 3 bulan. Batang bawah yang digunakan juga disesuaikan dengan pengelompokan yang menjadi indikator pemilihan rancangan lingkungan yang digunakan, yaitu kelompok 1 berumur 4 bulan, kelompok 2 berumur 6 bulan, dan kelompok 3 berumur 8 bulan. Mata tempel atau entres diambil dengan memotong bagian ranting, dan memilih entres yang telah mengeluarkan bakal tunas agar lebih efektif dalam waktu pecahnya tunas. Pemotongan ranting maksimal 7 mata tempel agar lebih memudahkan pada saat memegang ketika melakukan okulasi. Entres juga harus mudah dikupas dengan kuku yang menandakan entres tersebut memiliki sel kambium yang baik dan masih aktif melakukan pembelahan sel. Selain itu juga terhindar dari hama dan penyakit, hanya diperuntukan untuk penyediaan entres, dan telah lebih berumur 3 tahun (pohon induk).

3. Pelaksanaan okulasi

Pelaksanaan okulasi dilakukan dalam waktu satu hari, disaat cuaca sedang cerah. Penempelan mata entres $\pm 15 \mathrm{~cm}$ dari pangkal batang bawah. Kemudian sayat batang bawah yang akan ditempelkan entres dengan membuat jendela (mata tempel harus lebih kecil dibanding sayatannya) atau menyayat kulit batang bawah yang nantinya sesuai dengan entres yang akan di tempelkan. Menyayat batang bawah tidak boleh terlalu lama terbuka di khawatirkan kambium pada batang bawah akan kering sehingga dapat terjadinya kegagalan menyatunya mata tempel. Kemudian jika telah menempelkan entres pada batang bawah tadi, segera untuk mengikat tempelan tersebut dengan menggunakan plastik yang transparan dengan rapat agar tidak terkena bias hujan yang menyebabkan meresapnya air kedalam tempelan sehingga kambium dapat terinfeksi dan tidak menyatunya tempelan entres tersebut. Letakkan kembali bibit yang telah diokulasi ketempat yang telah di tata sesuai dengan tata letak (lay out) dengan memberi jarak antar polybag agar memudahkan pada saat pengamatan, perawatan, dan sebagainya.

4. Pembukaan pembungkus okulasi

Pembukaan pembungkus okulasi pada umur 21 hari setelah pelaksanaan okulasi. Selanjutnya melakukan pemeriksaan berhasil tidaknya pengokulasian. Plastiknya di buka dan diamati mata tempelannya, apabila warna mata tempelan itu terlihat kehitaman, ini berarti pengokulasian tidak berhasil atau mata tempelannya mati, tetapi jika mata tempelan terlihat merah tua, goresannya hijau segar dan sudah melekat dengan batang pokok, ini menandakan bahwa okulasi tersebut berhasil. Batang pokok pada okulasi yang berhasil, dipotong ujung tunasnya dengan menggunakan gunting, agar pertumbuhan tunas fokus pada mata tempel.

5. Penyulaman

Dilakukan pada umur 21 hari setelah okulasi dengan mengganti tanaman yang tunas mata tempelnya mati atau tidak normal dengan tanaman yang sudah disiapkan dari cadangan. Pada saat pelaksanaan, tidak ada tanaman yang mati pada tanaman sampel

6. Pemupukan

Dilakukan sesuai dengan taraf perlakuan pada umur 21 hari dan 51 hari setelah okulasi, dengan setengah konsentrasi pada saat pemupukan. Cara pengaplikasiannya dengan menyemprotkan di sekeliling tanaman (media tanam) dan pada daun tanaman. pemupukan melalui daun yaitu menyemprotkan pada bagian bawah daun ketika stomata membuka pada pagi hari.

7. Pemangkasan daun batang pokok

Pemangkasan daun batang pokok dilakukan pada saat daun yang tumbuh pada mata tempel telah mencapai 2 helai. Pangkas daun tua dan tunas yang tumbuh dibatang pokok (kecuali tunas okulasi) yang bertujuan untuk memacu pertumbuhan pada mata tempel.

8. Penyiraman 
Dilakukan pada semua media tanam, setiap pagi dan sore hari dengan volume 220 $\mathrm{ml}$ polybag $^{-1}$. Jika turun hujan, maka tidak dilakukan penyiraman, yang disesuaikan apakah hujan tersebut turun sebelum pagi atau sore hari

9. Penyiangan

Dilakukan dengan cara mencabut gulma dalam polybag, sedangkan yang tumbuh disekitar polybag dibersihkan dengan menggunakan lingga. Penyiangan dilakukan setiap dua minggu sekali.

10. Pengendalian hama dan penyakit

Pengendalian hanya dilakukan secara manual, mengambil hama yang menyerang menggunkan tangan. Pada saat awal sampai akhir pengamatan tidak ada gangguan hama maupun penyakit.

\section{Parameter Pengamatan}

Adapun beberapa parameter data untuk diamati, terdiri dari :

1. Umur pecah tunas (hari)

Diamati setelah membuka plastik pada mata tempel (okulasi). Pengamatan yang dilakukan yaitu, mengamati/ melihat pecahnya mata tunas setiap hari, pada pagi hari. Dan di hitung setelah pelaksanaan okulasi.

2. Panjang Tunas $(\mathrm{cm})$

Diukur pada tanaman berumur 51 dan 72 hari setalah okulasi. Dimulai dari pangkal mata tunas sampai pada titik pucuk meristem. 3. Jumlah daun (helai)

Dihitung pada umur 51 dan 72 hari setalah okulasi. Daun yang dihitung adalah daun yang sudah tumbuh dengan sempurna yaitu berbentuk sebagaimana bentuk daun dewasa dan sudah berwarna hijau, di titik mata tempel tersebut tumbuh.

4. Pertambahan diameter batang bawah $(\mathrm{cm})$

Diukur pada umur 51 dan 72 hari setelah okulasi, $\pm 10 \mathrm{~cm}$ dari atas permukaan tanah yang diberi tanda menggunakan sepidol permanen.

\section{Analisis Data}

Data yang terkumpul dari hasil penelitian dianalisis dan ditampilkan dalam tabbel sidik ragam. Jika pada sidik ragam menunjukan adanya pengaruh nyata atau sangat nyata, akan dilanjutkan dengan Uji Beda Nyata Jujur (BNJ) taraf 5\%.

\section{HASIL DAN PEMBAHASAN}

\section{Umur Pecah Tunas}

Berdasarkan hasil pengamatan menunjukkan bahwa konsentrasi pupuk organik cair (POC) agrib kompos memberikan pengaruh sangat nyata terhadap rata-rata umur pecah tunas okulasi bibit lai (Gambar 1). Umur pecah tunas tercepat diperoleh pada perlakuan $\mathrm{p}_{7}\left(14 \mathrm{ml} \mathrm{L}^{-1}\right.$ air) yaitu 29,2 hari, yang tidak berbeda nyata dengan perlakuan $\mathrm{p}_{2}, \mathrm{p}_{3}, \mathrm{p}_{4}, \mathrm{p}_{5}$, dan $\mathrm{p}_{6}$, namun berbeda nyata dengan perlakuan $\mathrm{p}_{0}$ dan $\mathrm{p}_{1}$. Sedangkan umur pecah tunas terlama diperoleh pada perlakuan $\mathrm{p}_{0}$ (kontrol) yaitu 33,2 hari, yang tidak berbeda nyata dengan perlakuan $\mathrm{p}_{1}, \mathrm{p}_{2}, \mathrm{p}_{3}$, dan $\mathrm{p}_{4}$

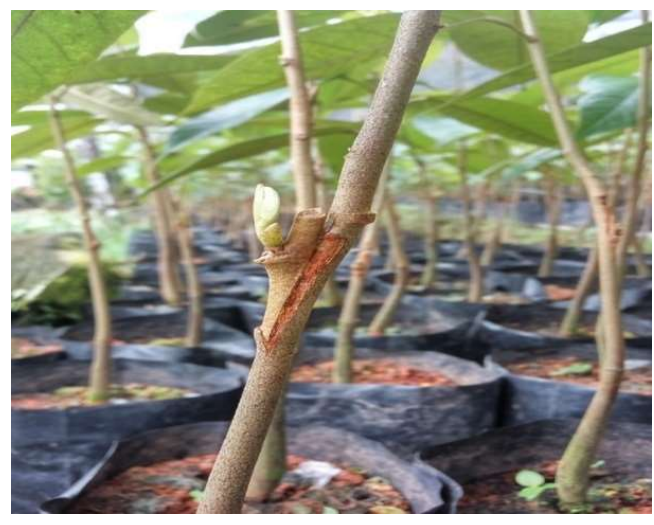

Gambar 1. Pecah tunas okulasi bibit lai 
namun berbeda nyata dengan perlakuan $\mathrm{p}_{5}, \mathrm{p}_{6}$, dan $\mathrm{p}_{7}$ (Gambar 2). Adanya konsentasi POC agrib kompos mempengaruhi kecepatan pecahnya tunas okulasi bibit lai. Semakin tinggi konsentrasi POC agrib kompos yang diberikan, semakin cepat munculnya tunas okulasi bibit lai. Hal ini diduga POC agrib kompos mengandung hormon yang mempercepat proses inisiasi munculnya tunas. Menurut Meori (2018), POC mengandung sitokinin seperti kinetin dengan konsentrasi $37,55 \mathrm{ppm}$ dan zeatin $39,72 \mathrm{ppm}$ yang berfungsi dalam pembelahan sel, selain itu juga mengandung hormon giberelin (GA3) dengan konsentrasi 128,13 ppm yang berfungsi dalam pertumbuhan tunas.

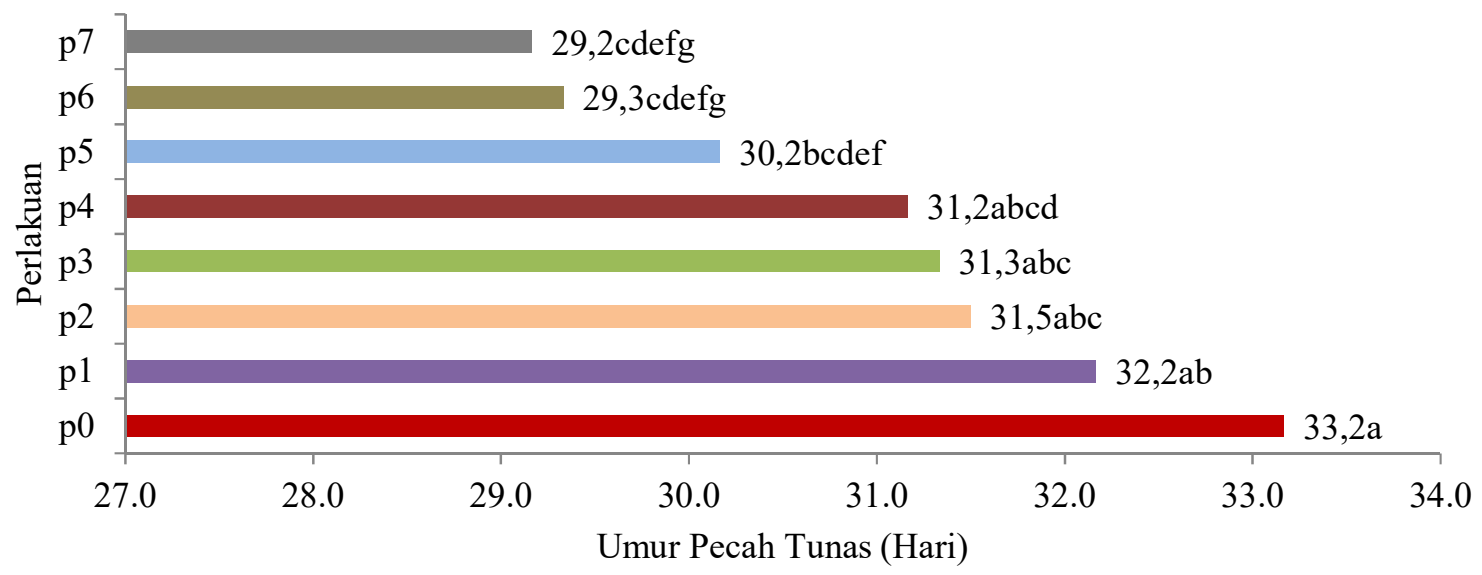

Keterangan: $\mathrm{p} 0=$ kontrol, $\mathrm{p} 1=2 \mathrm{ml} \mathrm{L}-1$ air, $\mathrm{p} 2=4 \mathrm{ml} \mathrm{L}^{-1}$ air, $\mathrm{p} 3=6 \mathrm{ml} \mathrm{L}^{-1}$ air, $\mathrm{p} 4=8 \mathrm{ml} \mathrm{L}^{-1}$ air, p5 $=10 \mathrm{ml} \mathrm{L}^{-1}$ air, p6 $=12 \mathrm{ml} \mathrm{L}^{-1}$ air, p7 $=14 \mathrm{ml} \mathrm{L}^{-1}$ air

Gambar 2. Umur pecah tunas okulasi bibit lai

Wiraatmaja (2017) menambahkan bahwa zat pengatur tumbuh saling bekerja secara berinteraksi, baik antara giberelin dengan sitokinin maupun dengan auksin dalam pertumbuhan tanaman. Interaksi tesebut dapat memacu pertumbuhan dan pembelahan sel dengan cepat pada pertumbuhan vegetatif seperti plumula, tunas baru, dan organ lain yang sangat respon terhadap zat pengatur tumbuh tersebut, dengan melalui jaringan-jaringan pembuluh floem dan xylem dan juga melalui sistem apoplas dan simplas.

\section{Panjang Tunas}

Pemberian POC agrib kompos dengan berbagai konsentrasi memberikan pengaruh tidak nyata terhadap rata-rata panjang tunas okulasi bibit lai umur 51 dan 72 hari setelah okulasi. Saat umur 51 hari setelah okulasi diperoleh rata-rata panjang tunas tertinggi pada perlakuan $\mathrm{p}_{7}\left(14 \mathrm{ml} \mathrm{L}^{-1}\right.$ air) yaitu sebesar $6,2 \mathrm{~cm}$ dan terendah pada perlakuan $\mathrm{p}_{0}$ (kontrol) yaitu sebesar 2,6 cm. Sedangkan saat umur 72 hari setelah okulasi rata-rata panjang tunas tertinggi diperoleh pada perlakuan $\mathrm{p}_{7}\left(14 \mathrm{ml} \mathrm{L}^{-1}\right.$ air $)$ yaitu sebesar 7,3 cm dan terendah pada perlakuan $\mathrm{p}_{0}$ (kontrol) yaitu sebesar 3,3 cm (Tabel 1). 
Tabel 1. Rata-rata panjang tunas umur 51 dan 72 hari setelah okulasi $(\mathrm{cm})$

\begin{tabular}{ccc}
\hline \multirow{2}{*}{ Perlakuan POC agrib kompos } & \multicolumn{2}{c}{ Rata-rata panjang tunas (cm) } \\
\cline { 2 - 3 } & Umur 51 hari & Umur 72 hari \\
\hline kontrol (p0) & 2,6 & 3,3 \\
$2 \mathrm{ml} \mathrm{L}^{-1}$ air (p1) & 3,1 & 4,2 \\
$4 \mathrm{ml} \mathrm{L}^{-1}$ air (p2) & 3,5 & 4,7 \\
$6 \mathrm{ml} \mathrm{L}^{-1}$ air (p3) & 3,8 & 4,5 \\
$8 \mathrm{ml} \mathrm{L}^{-1}$ air (p4) & 3,8 & 4,9 \\
$10 \mathrm{ml} \mathrm{L}^{-1}$ air (p5) & 4,1 & 5,5 \\
$12 \mathrm{ml} \mathrm{L}^{-1}$ air (p6) & 5,7 & 6,6 \\
$14 \mathrm{ml} \mathrm{L}^{-1}$ air (p7) & 6,2 & 7,3 \\
\hline Uji F & tn & tn
\end{tabular}

Keterangan: $\mathrm{tn}=$ berpengaruh tidak nyata pada taraf $\alpha=5 \%$

Panjang tunas dipengaruhi oleh kandungan beberapa unsur hara, selain itu juga zat pengatur tumbuh untuk memacu pertumbuhan saat fase vegetatif. Dalam hal ini diduga bahwa panjang tunas yang tidak berpengaruh nyata dipengaruhi oleh tidak tercukupinya unsur $\mathrm{N}$ (nitrogen) yang kandungan kumulatifnya sangat rendah, hanya berkisaran $0,12 \%$ (Tabel 2). Hal tersebut sependapat dengan Novizan (2005), nitrogen adalah komponen utama dari berbagai substansi penting di dalam tanaman. Sekitar 40-50 \% kandungan protoplasma yang merupakan substansi hidup dari sel tumbuhan terdiri dari senyawa nitrogen. Nitrogen sangat dibutuhkan pada tahap pertumbuhan vegetatif seperti pertumbuhan tunas, daun dan perkembangan batang.

Tabel 2. Hasil analisis laboratorium pada POC agrib kompos

\begin{tabular}{|c|c|c|c|c|c|c|c|c|c|c|c|}
\hline \multirow{3}{*}{ No } & \multirow{3}{*}{ Sampel } & $\mathrm{pH}$ & $\mathrm{N}$ & \multicolumn{5}{|c|}{ Makro } & \multicolumn{3}{|c|}{ Mikro } \\
\hline & & $\mathrm{H}_{2} \mathrm{O}$ & Total & $\mathrm{P}$ & $\mathrm{K}$ & $\mathrm{Na}$ & $\mathrm{Ca}$ & $\mathrm{Mg}$ & $\mathrm{Fe}$ & $\mathrm{Zn}$ & $\mathrm{Cu}$ \\
\hline & & & \multicolumn{6}{|c|}{$\%$} & \multicolumn{3}{|c|}{$\mathrm{ppm}$} \\
\hline 1 & $\begin{array}{l}\text { POC } \\
\text { agrib } \\
\text { kompos }\end{array}$ & 8,4 & 0,12 & 0,01 & 1,00 & 0,02 & 0,00 & 0,02 & 0,00 & 0,00 & 0,00 \\
\hline
\end{tabular}

Sumber: BPTP Kaltim (2018)

\section{Jumlah Daun}

Pemberian POC agrib kompos dengan berbagai konsentrasi memberikan pengaruh tidak nyata terhadap rata-rata jumlah daun okulasi bibit lai umur 51 dan 72 hari setelah okulasi. Data yang disajikan pada Tabel 3 menunjukkan bahwa saat umur 51 hari setelah okulasi diperoleh rata-rata jumlah daun tertinggi pada perlakuan $\mathrm{p}_{7}\left(14 \mathrm{ml} \mathrm{L}^{-1}\right.$ air $)$ yaitu sebanyak 2,8 helai dan terendah pada perlakuan $\mathrm{p}_{0}$ (kontrol) yaitu sebanyak 1,0 helai. Sedangkan saat umur 72 hari setelah okulasi rata-rata jumlah daun tertinggi diperoleh pada perlakuan $\mathrm{p}_{7}\left(14 \mathrm{ml} \mathrm{L}^{-1}\right.$ air $)$ yaitu sebanyak 4,3 helai dan terendah pada perlakuan $\mathrm{p}_{0}$ (kontrol) yaitu sebanyak 1,8 helai.

Hasil yang menunjukkan pengaruh tidak nyata disebabkan karena rendahnya kandungan unsur N (nitrogen) total pada POC agrib kompos yang hanya sebesar $0,12 \%$ (Tabel 2), sehingga tidak dapat memenuhi kebutuhan secara optimal. Pertumbuhan calon pucuk pada tunas okulasi akan menentukan banyaknya jumlah daun, sehingga peranan unsur $\mathrm{N}$ (nitrogen) sangat berpengaruh bagi 
pertumbuhan pucuk yang berlanjut pada pembentukan daun. Hal ini sesuai dengan pernyataan Wahyudi (2010), bahwa N (nitrogen) merupakan salah satu unsur hara yang sangat berperan pada pertumbuhan daun, sehingga daun tanaman menjadi lebih lebar, berwarna lebih hijau dan lebih banyak tumbuh sehingga dapat menghasilkan fotosintat yang tinggi.

Tabel 3. Rata-rata jumlah daun umur 51 dan 72 hari setelah okulasi (helai)

\begin{tabular}{ccc}
\hline \multirow{2}{*}{ Perlakuan POC agrib kompos } & \multicolumn{2}{c}{ Rata-rata jumlah daun (helai) } \\
\cline { 2 - 3 } & Umur 51 hari & Umur 72 hari \\
\hline $0 \mathrm{ml} \mathrm{L}^{-1}$ air (p0) & 1.0 & 1.8 \\
$2 \mathrm{ml} \mathrm{L}^{-1}$ air (p1) & 1.5 & 3.0 \\
$4 \mathrm{ml} \mathrm{L}^{-1}$ air (p2) & 1.5 & 3.5 \\
$6 \mathrm{ml} \mathrm{L}^{-1}$ air (p3) & 1.7 & 3.3 \\
$8 \mathrm{ml} \mathrm{L}^{-1}$ air (p4) & 2.2 & 4.0 \\
$10 \mathrm{ml} \mathrm{L}^{-1}$ air (p5) & 2.3 & 4.0 \\
$12 \mathrm{ml} \mathrm{L}^{-1}$ air (p6) & 2.5 & 4.0 \\
$14 \mathrm{ml} \mathrm{L}^{-1}$ air (p7) & 2.8 & 4.3 \\
\hline Uji F & tn & tn
\end{tabular}

Keterangan: $\mathrm{tn}=$ berpengaruh tidak nyata pada taraf $\alpha=5 \%$

Pertambahan Diameter Batang Bawah

Hasil pengamatan dan analisis data menunjukkan bahwa pemberian POC agrib kompos dengan berbagai konsentrasi memberikan pengaruh tidak nyata terhadap rata-rata pertambahan diameter batang bawah okulasi bibit lai umur 51 dan 72 hari setelah okulasi. Perlakuan menunjukan hasil yang relatif sama dan seragam pada perlakuan $\mathrm{p}_{0}$ (kontrol) sampai perlakuan $\mathrm{p}_{7}\left(14 \mathrm{ml} \mathrm{L}^{-1}\right.$ air), dengan nilai rata-rata $0,5 \mathrm{~cm}$ saat umur 51 dan $0,6 \mathrm{~cm}$ saat umur 72 hari setelah okulasi.

Tabel 4. Rata-rata pertambahan diameter batang bawah umur 51 dan 72 hari setelah okulasi (cm)

\begin{tabular}{ccc}
\hline \multirow{2}{*}{ Perlakuan POC agrib kompos } & \multicolumn{2}{c}{ Rata-rata diameter batang $(\mathrm{cm})$} \\
\cline { 2 - 3 } $0 \mathrm{ml} \mathrm{L}^{-1}$ air (p0) & Umur 51 hari & Umur 72 hari \\
$2 \mathrm{ml} \mathrm{L}^{-1}$ air (p1) & 0.5 & 0.6 \\
$4 \mathrm{ml} \mathrm{L}^{-1}$ air (p2) & 0.5 & 0.6 \\
$6 \mathrm{ml} \mathrm{L}^{-1}$ air (p3) & 0.5 & 0.6 \\
$8 \mathrm{ml} \mathrm{L}^{-1}$ air (p4) & 0.5 & 0.6 \\
$10 \mathrm{ml} \mathrm{L}^{-1}$ air (p5) & 0.5 & 0.6 \\
$12 \mathrm{ml} \mathrm{L}^{-1}$ air (p6) & 0.5 & 0.6 \\
$14 \mathrm{ml} \mathrm{L}^{-1}$ air (p7) & 0.5 & 0.6 \\
\hline Uji F & 0.5 & 0.6 \\
\hline
\end{tabular}

Keterangan: $\operatorname{tn}=$ berpengaruh tidak nyata pada taraf $\alpha=5 \%$ 
Uraian di atas menunjukkan peningkatan pertambahan diameter batang bawah saat umur 51 sampai pengamatan 72 hari setelah okulasi, dengan rentang nilainya hanya meningkat $1 \mathrm{~mm}$ pada pertambahan diameter batang bawah diantara umur 51 dan 72 hari setelah okulasi. Hal ini diduga dari beberapa unsur yang terkandung dalam pupuk organik cair agrib kompos tidak memberikan pengaruh yang nyata terhadap pertambahan diameter batang bawah. Pemberian pupuk organik tidak meningkatkan basa-basa tanah seperti unsur $\mathrm{Mg}$ dan K secara nyata pada pertambahan diameter batang bawah. Unsur-unsur tersebut dibutuhkan untuk pertumbuhan kayu atau perkembangan diameter batang (Zulfia, 2015).

Hasil uji laboratorium BPTP Kaltim, dengan sampel POC agrib kompos (Tabel 2), menujukkan bahwa POC agrib kompos mengandung unsur $\mathrm{Mg}=0,02 \%$ dan $\mathrm{K}=1,00 \%$. Berdasarkan hasil analisis POC agrib kompos tersebut dapat diketahui bahwa unsur yang tersedia di dalam pupuk tersebut sangatlah kecil sehingga tidak memberikan dampak perubahan yang nyata pada pertambahan diameter batang bawah.

\section{KESIMPULAN DAN SARAN}

\section{Kesimpulan}

Berdasarkan penelitian yang telah dilakukan, dapat disimpulkan bahwa pemberian pupuk organik cair agrib kompos berpengaruh sangat nyata pada parameter umur pecah tunas, perlakuan tertinggi pada $\mathrm{p}_{7}\left(14 \mathrm{ml} \mathrm{L}^{-1}\right.$ air $)$ dengan nilai rata-rata 29,2 hari setelah okulasi, dan hasil terendah pada perlakuan $\mathrm{p}_{0}$ (kontrol) dengan nilai rata-rata 33,2 hari setelah okulasi.

Pemberian pupuk organik cair agrib kompos berpengaruh tidak nyata terhadap parameter panjang tunas, jumlah daun dan pertambahan diameter batang bawah pada umur 51 dan 72 hari setelah okulasi. Rata-rata hasil tertinggi panjang tunas dan jumlah daun yaitu pada perlakuan $\mathrm{p}_{7}\left(14 \mathrm{ml} \mathrm{L}^{-1}\right.$ air $)$ dan hasil terendah pada perlakuan $\mathrm{p}_{0}$ (kontrol), tetapi pada rata-rata hasil pertambahan diameter batang bawah menunjukan nilai yang relatif sama untuk semua perlakuan.

\section{Saran}

Berdasarkan hasil penelitian yang telah dilakukan dapat dikemukakan saran yaitu perlu menambahkan waktu pengamatan agar dapat diketahui apakah masih dapat terjadi pertumbuhan yang optimum pada okulasi bibit lai Mahakam.

\section{DAFTAR PUSTAKA}

Balai Pengkajian Teknologi Pertanian (BPTP) Kaltim. 2018. Analisis laboratorium POC agrib kompos. Laboratorium Tanah, Tanaman, Pupuk, Air, Badan Penelitian dan Pengembangan Pertanian. BPTP. Samarinda.

Dinas Pertanian Tanaman Pangan dan Hortikultura Kabupaten Kutai Kartanegara, 2018. Laporan tahunan 2017. Dinas Pertanian Tanaman Pangan dan Hortikultura Kabupaten Kutai Kartanegara, Tenggarong.

Lisdiyanti, P. 2011. Sukses Membuat Pupuk Cair. Indocam. Kebayoran baru, Jakarta Selatan.

Meori. 2018. Biang pupuk hayati pupuk organik cair dan kompos bio triba (BT2). http:// www.meori-agro.co.id. Diakses pada tanggal 20 April 2018.

Novizan. 2005. Petunjuk Pemupukan yang Efektif. PT. Agromedia Pustaka. Jakarta.

Priono, A. 2018. Perbanyakan tanaman lai secara vegetatif (okulasi) dan pupuk organik cair agrib kompos. Loa Janan, Kutai Kartanegara, Kalimantan Timur.

Rizal, M., S.P. Rahayu, A. Supriono. 2015. Prospek pengembangan buah lai sebagai varietas unggul lokal di kabupaten kutai kartanegara Kalimantan timur. Prosiding Seminar Nasional Masyarakat Biodiversitas Indonesia Vol. 1 (6). Halaman: 1497-1501. ISSN: 2407-8050. DOI: $10.13057 / \mathrm{psnmbi} / \mathrm{m} 010641$. 
Santoso, P.J. dan A. Priono. 2015. Wiraatmaja, I. 2017. Zat Pengatur Tumbuh Pengembangan dan pelestarian tanaman Giberelin dan Sitokinin. Fakultas endemik lokol lai (Durio kutejensis) di kabupaten kutai kartanegara, Balai Penelitian Tanaman Buah Tropika, Sumatera barat dan Badan Ketahanan Pangan dan Penyuluhan, Tenggarong, Kutai Kartanegara, Kalimantan Timur.

Wahyudi. 2010. Petunjuk Praktis Bertanam Komoditas Hortikultura. Agromedia Pustaka. Jakarta.

Zulfia, D. 2015. Pengaruh Pupuk Kompos Terhadap Pertumbuhan Awal Bibit Durian (Durio zibethinus Murr). Skripsi. Program Studi Agroteknologi Fakultas Pertanian Universitas Kutai Kartanegara. Tenggarong. 